\title{
Aesthetics and ecology in the post-modern perspective ${ }^{\dagger}$
}

\section{Anna Zeidler-Janiszewska}

\begin{abstract}
The analysis sets out from the exhibition entitled Ressource Kunst. Die Elemente Neu Gesehen. The author attempts to outline an area which emerges from the encounter of ecology (as a domain of reflection about the human surroundings) and aesthetics (as a discipline concerned with sensory experience) from the standpoint of post-modernism. The inquiry thus focuses on the moment in which contemporary artistic practices "internalize" ecological issues. Aesthetics becomes a branch of ecology, but at the same time ecology becomes a domain within aesthetics. According to the author, post-modernism has offered advantageous perspectives for pursuing ecological postulations.
\end{abstract}

Key words

Aesthetics, art, ecology, post-modernism

In 1989, Berlin (still West Berlin at the time) saw an extensive international exhibition (or rather a network of events) initiated by the city's Senate: Ressource Kunstdie Elemente neu gesehen (Jappe 1989). On the cover flap of the book under the same title, which documented that political-artistic undertaking (supplemented with critical texts and brief pre-history of the "new seeing"), one reads that until recently the eponymous term had been largely associated with the material and energetic resources of nature, which appeared to be "gushing gifts of life," gifts that were inexhaustible and therefore widely and freely exploited. Today the notion is accompanied by ecological awareness determined by the principle of responsibility. According to the organizers, the tenet is implemented in art by a new generation of artists who, on the one hand, go beyond the confines of the paradigm of optimistic (progressive) modernity and, on the other, transcend "land art," "arte povera," or the experiments of Joseph Beuys. As it turns out, in contemporary times there is

† The original version of this text appeared as "Estetyka i ekologia w perspektywie postmodernistycznej," in Estetyka a ekologia[Aesthetics and Ecology], edited by K. Wilkoszewska, Kraków: Uniwersytet Jagielloński 1992, 81—88. 
“an urgent need" to seek alternative locations, find materials which neither suffer nor cause harm, look for devices which provoke no injury, "means of approaching objects" instead of the erstwhile methods of "taking them in possession". In other words, considerable portions of today's artistic practice cease to be merely an illustration of ecological issues but, in a manner of their own, internalize it.

In this approach, aesthetics becomes a fragment of ecology or-depending on how the scope of the notions is "trimmed"-ecology becomes a component of aesthetics. The conclusion may appear far-fetched, yet it suggested itself in the context of the exhibition and the critical deliberations which accompanied it, as well as in the cases of numerous similar initiatives in Germany, the Netherlands, and other European countries.

It needs to be added that the exhibition in question was very much governed by the spirit of pluralism with respect to forms of expression: lectures and presentations concerned with the "pre-history" of the issue co-existed with new projects in the domain of autonomous art and diverse events, stagings, etc., which integrated various "extra-artistic" context. Likewise, diversified roles were assigned to the audience-the participants of the entire undertaking.

One of the more significant elements which determined the novelty of how ecological issues were addressed by artists, critics, and theorists contributing to Ressource Kunst, is that they abandoned certain traditional notions of contexts of art, departing from the division between "the artificial" and "the natural," that is, from the typical Enlightenment critical juxtaposition of good nature and evil, destructive culture (the scientific-technological domain of human experience in particular). 1

The new "ecological-aesthetic" thought forgoes both the myth of victorious technology, so characteristic of the Enlightenment paradigm, and the opposing myth of good, "true" (profound) nature, which became marred over the centuries (a concept embedded in the self-critical myth of modernity). In fact, all oppositions of the kind are done away with. The issue I outline here boils down to an attempt to delineate the area that emerges in the encounter of ecology (meaning the domain of reflection on human surroundings) with aesthetics (as a domain concerned etymologically and in the broadest sense with sensations) in light of a current which is fairly universally referred to as "post-modernity" or "post-modernism." (Frederic Jameson (1991) terms it "cultural dominant", whereas Charles Newman (1985) would probably call it an "aura") The very name is not devoted particular attention here: thousands of pages written on that topic preclude the introduction of a relatively stable definition-even less is devoted to its elucidation, which would undoubtedly require a separate, extensive volume. For the purposes of these deliberations, I employ the term "post-modernity" which is perhaps not the most felicitous a label

1 The myths which traditionally molded such an understanding of ecology and aesthetics are discussed by Krystyna Wilkoszewska (1992). 
for this new type of thinking. It arises from the critique of post-Enlightenment culture ("modernity") and aspires toward a positive conceptualization of the "signs of the times." It aims at determining the directions in which varied cultural practices develop in civilizationally advanced societies.

The statement cited at the outset, which provided a kind of ideological framework for the Ressource Kunst initiative, characterizes only one past current-the theme of the victorious conquest of nature by humans convinced of their boundless capabilities. As we know, a parallel critical current emerged in the bosom of modernity, for which the names of Jean-Jacques Rousseau and Theodor W. Adorno-quoted by Hans-Robert Jauss in a slightly different context-establish a symbolic frame.

The development of science, which gained positive appraisal in modern epistemological thought and its associated anthropology, becomes something akin to "negative ecology" when assessed by the critical current of modernity. The hubris of the subject who humanizes their surroundings is seen here as a kind of injury or harm inflicted upon nature. And although the "harm" was variedly described in different philosophical concepts which made up the current of the modern critique of culture, an important "therapeutic" role tended to be assigned to art or (more broadly) to the domain of aesthetic experience. It was art that would be capable of working towards future "liberation" of the inner and exterior nature of the human. This is how it was envisioned by, for instance, Max Weber, one of the most eminent representatives of the critical discourse of modernity, as he described the "iron cage" in which we were to be trapped-as he prophesied-as a result of increased "upward rationalization" (scientific-technological-bureaucratic) against the potential for spontaneity inherent in erotic and aesthetic experience. Weber's views in that respect bear astonishing similarity to ideas propagated completely independently by the Surrealist movement.

The theme of "harmed nature" construed in the Weberian spirit enhanced by psychoanalysis is elaborated by Max Horkheimer and Theodor W. Adorno in their Dialectic of Enlightenment. They consider Odysseus, the prototype of the later victorious subject of modernity, the first malefactor to harm nature: both the external one, which he successfully outsmarts, and the inner one, which becomes evident in authoritarian societies. The negative impact of the process of civilization in the context of "harmed nature" is not only analyzed in Dialectic of Enlightenment but also in the later writings of both authors, such as Eclipse of Reason, Negative Dialectics, and numerous critical essays. And, while later Horkheimer turned for succor to the sphere of religious experience, Adorno remained faithful to art, which in its contemporary form of "dried up, tearless weeping" (Adorno 1991, 252) may still preserve something "natural." "This opening up relies on a kind of anamnesis - a return to the original sources, that is to the primeval magic (symbiotic contact between human and nature, whose remnants can be traced in mimesis) [...] [however] [...] mimetic thought is merely on the horizon of Adorno's vision: 
the enlightenment of Enlightenment by a notion transcending the notional sphere proves to be no more than a nostalgic project. In Minima Moralia, one reads that it is unattainable and whether it can be implemented or not is really without consequence. What counts, however, is a constant overcoming of the status quo as one strives for the magical mimesis" (Morawski 1992, 98-10o). Stefan Morawski, whose interpretation is quoted here, draws attention to the similarities and differences linking (and dividing) Adorno's and Ernst Bloch's conceptions. The latter was most likely more optimistic when (in Prinzip Hoffnung) he anticipated rapprochement with the creative hearth of the natural world which, combined with transformation of the thing-in-itself into thing-for-itself, will make the world a home for everyone. ${ }^{2}$

The utopian horizon of "reconciliation with nature" in the spirit of renewed "settling in" may be found in another tradition of thought-namely, in hermeneutic tradition (also decidedly critical of Enlightenment and post-Enlightenment modernity). I am thinking in particular about the Heideggerian vision of the "magical square" which, once the history of "forgottenness of being" (metaphysics) is through, inspires and renews past "thinking." (Heidegger, 1971) It is also present in art, especially in poetry, a domain to which intimate contact with "being" is sometimes accessible. In one of his essays, Heidegger quotes Rilke's letter, where the poet observes that "even for our grandparents a 'house,' a 'well', a familiar tower, their very clothes, their coat: were infinitely more, infinitely more intimate; almost everything a vessel in which they found the human and added to the store of the human. Now, from America, empty indifferent things are pouring across, sham things, dummy life ...A house, in the American sense, an American apple or a grapevine over there, has nothing in common with the house, the fruit, the grape into which went the hopes and reflections of our forefathers" (Rilke 1948, 374-375; see Heidegger 2001). ${ }^{3}$ Only poetry, as "becoming and happening of truth" can still "let being speak and arise," as we read in the famed essay The Origin of the Work of Art (Heidegger 2002, 16).

The utopian horizon which to a greater or lesser extent is tangible in the concepts cited here, conveys visions of reconciliation with nature structured along nostalgic lines. The past (highly idealized) became a kind of paradise lost. In this sense, the "ecological-aesthetic" project in those conceptions belongs to the sphere of "grand narratives" - as Lyotard (1984) puts it-that were intrinsic to modernity. This happens even if-fortuitously-one is clearly aware that the grand narratives can survive only in tiny shards, in fragments, in the nebulous form of "micrology," to use Adorno's words.

The new philosophical thought identified with post-modernity presumes that oikos will no longer be the erstwhile cosmos, nor any lasting structure in which humans could feel permanently safe. On the contrary-it is in constant motion

2 On that issue, see Czajka (1991).

3 I discussed these questions more comprehensively in Zeidler-Janiszewska (1988). 
due to the nomadic status of the subject, their "migration," being in-between various partial contexts of action.

The post-modern subject lives in pluralized culture and projects that pluralismas a principle-into themselves. As Welsch, one of the foremost proponents of the post-modern worldview (however odd that may sound) claims, life in the postmodern condition is a life in the plural-both externally and internally, meaning both living in various social and cultural contexts and living which, in its fashion and method, can course through and constellate many projects of that kind (Welsch 1992, 87). ${ }^{4}$ At the same time, that subject-versed in the critical discourse of modernity-is deprived of stable underpinning: they are rather a weak subject (according to Gianni Vattimo (1991)) who, paradoxically, tries to turn the weakness of which they are conscious and their limitations into strength. The subject must be equipped with particular sensibility, the capacity for sensing otherness andin their own way-accepting it. Lyotard (1984) states that they are characterized by "agility and flexibility," which precisely means a special set of aesthetic skills "trained" in twentieth-century art in particular. Today, we have to be able to move about in the world as we have done for years (successfully, in a way) in the realm of simultaneously pluralized and individualized artistic practice. For this reason, art and aesthetics broadly understood become, in a sense, paradigmatic domains of contemporary experience. They encompass the entirety of human surroundings, the human home in the broadest sense, which after all is a province of ecology. As noted on many occasions by e.g. Jean-François Lyotard and Wolfgang Welsch, as well as Zygmunt Bauman, who describes post-modernity somewhat from the outside, the post-modern subject bears sole responsibility for the outcomes of their action; they are aware that they will not be exonerated by God, Nature, or any other transcendental norms.

The new art exhibited at Ressource Kunst grows out from that particular awareness; it does not catechize nor persuade, knowing it has no right to do so. It only demonstrates how one can individually "handle" all that which becomes human environment, how to engage in a sensory, emotional, and intellectual dialogue with it, how to treat surroundings as a partner rather than an object of manipulation, how-in other words-ecological ethics and politics become aesthetics in specific artistic or para-artistic activities. What is more, artists encourage others to do likewise by exposing the very attitude of sensibility towards the environment of each human being; they show how the world in which we live can be aesthetically problematized, whereby "aesthetically" means at the same time responsibly and therefore ethically. In contrast to grand narratives, which purported to take responsibility for the entirety of the future world and the shape of human happiness, the

4 See also his final observations on the status of the subject of contemporary culture in Welsch (1987). 
contemporary subject associates the project of successful life with the concretewith the here and now.

If this is how we construe the fundamental goals of the new, post-modern thinking, it becomes easy to demonstrate the essential difference with regard to previous tradition (cited here only fragmentarily) and-respectively-the difference between two possible cultural situations that those two modes of thinking seek to describe. The analysis of the post-Enlightenment model of scientific-technological progress and human ascendancy (a subject that is imperious, conquering, and self-assured) as well as alternative traditions (Dewey's pragmatism) provided substrate for the conviction that "we live in times, in which we no longer intensely experience the shrunken natural environment, or fine arts that are detached from life and, as yet, do not experience our everyday surroundings abundantly and fully" (Wilkoszewska 1990, 76). Post-modernist thinking and the associated artistic practice (which only partially encompasses that which artists and critics call "postmodernism" in architecture, visual arts, music, and literature $)^{5}$ brings us closer to the horizon which, in the above quote, follows "as yet."

Initiatives such as the one with which my deliberations started seem to demonstrate that the new thinking (defined at once as post-modernist and aesthetic) establishes a promising perspective as far as realization of ecological postulations is concerned. In his work devoted to that very thinking, Welsch $(1991,218)$ asserts that "our present and the expected future will be determined by two major directions: post-modernity and ecological demands. I believe that a juncture where these two directions coincide is viable. We know today that the entire human activity-from the designs of grand politics to family life, and from our communication systems to elusive, momentary sensations-is concurrent with that diagnosis. The age of transition in which we live is a time of remodeling in all domains."

Thus, art and aesthetics would have a pioneering role to play, which is a greatly optimistic notion given the unceasing laments of those who deplore the collapse, crisis, or even decline of both.

\section{References:}

Adorno, Theodor W. 1991. Notes to Literature, vol. 2. Translated by Rolph Tiedemann. New York: Columbia University Press.

Czajka, Anna. 1991. Człowiek znaczy nadzieja. O filozofii Ernesta Blocha [Human Stands for Hope: On Ernest Bloch's Philosophy]. Warsaw: FEA.

Heidegger, Martin. 1971. "Building, Dwelling, Thinking." In Martin Heidegger, Poetry, Language, Thought. Translated by Alfred Hofstadter, 143—62. New York: Harper \& Row.

5 Lyotard and, for instance, Welsch would qualify a substantial part of post-modern practices (e.g., those conceptualized by Jencks or Oliva) as belonging-at most-to the post-modernist "surface." 
Heidegger, Martin. 2001. "What Are Poets For?" In Martin Heidegger, Poetry, Language, Thought. Translated by Alfred Hofstadter, 87-139. New York: Harper \& Row.

Heidegger, Martin. 2002. "The Origin of the Work of Art." In Martin Heidegger, Off the Beaten Track. Edited and translated by Julian Young and Kenneth Heynes, 1-56. Cambridge: Cambridge University Press.

Jappe, Georg. 1989. Ressource Kunst. Die Elemente neu gesehen. Köln: DuMont Buchverlag. Jameson, Frederic. 1991. Postmodernism, or, the Cultural Logic of Late Capitalism. London: Verso. Lyotard, Jean-François. 1984. The Postmodern Condition: A Report on Knowledge. Translated by Geoff Benington. Manchester: Manchester University Press.

Morawski, Stefan. 1992. Główne nurty estetyki XX wieku [Main Trends in 20th Century Aesthetics]. Wrocław: Wiedza o kulturze.

Newman, Charles. 1985. Postmodern Aura: The Act of Fiction in an Age of Inflation. Evanston: Northwestern University Press.

Rilke, Rainer Maria. 1948. Letter of Rainer Maria Rilke. Volume 2 1910-1926. Translated by Jane Bannard Green and M.D. Herter Norton. New York: Norton.

Vattimo, Gianni. 1991. The End of Modernity: Nihilism and Hermeneutics in Postmodern Culture. Translated by Jon R. Snyder. Baltimore: John Hopkins University.

Welsch, Wolfgang. 1992. "Ku jakiemu podmiotowi_dla jakiego innego?" ["To What Subject_For Whom Else?"]. In Schelling o pojęciu subiektywności [Schelling on the Idea of Subjectivity], edited by Mirosława Czarnawska. Białystok: Idea.

Welsch, Wolfgang. 1991. Ästhetisches Denken. Stuttgart: Reclam.

Welsch, Wolfgang. 1987. Unsere postmoderne Moderne. Weinheim: VCH.

Wilkoszewska, Krystyna. 1990. "Estetyka ekologiczna" ["Ecological aesthetics"]. In Nauka o pięknie. Rozprawy z pogranicza estetyki, aksjologii ogólnej antropologii filozoficznej [The Science of Beauty: Papers on the Crossroads of Aesthetics, General Axiology, and Philosophical Anthropology], edited by Maria Gołaszewska. Kraków: Wydawnictwo UMCS.

Wilkoszewska, Krystyna. 1992. Sztuka jako rytm życia. Rekonstrukcja filozofii sztuki Johna Deweya [Art as the Rhythm of Life: A Reconstruction of John Dewey's Philosophy of Art]. Kraków: Wydawnictwo UJ.

Zeidler-Janiszewska, Anna. 1988. Sztuka, mit, hermeneutyka [Art, Myth, Hermeneutics]. Warsaw: Wydawnictwo Naukowe Instytutu Kultury MkiSz. 